\title{
HELLENISTIC AND PHARAONIC INFLUENCES ON THE FORMATION OF COPTIC IDENTITY
}

\author{
Annette Evans \\ Department of Ancient Studies \\ Stellenbosch University
}

\begin{abstract}
Conflicting descriptions of Coptic identity still exist today. The Copts regard themselves as those descendents of Pharaonic Egyptians who have retained their identity because of their Christian faith, in spite of Egypt having become a predominantly Islamic, Arab country. They claim to have "caught a glimpse of the Light of Christianity" before the birth of Christ. This article offers iconographical evidence to supplement an explanation of how the ancient Egyptian mythopoeic thinking, in combination with the syncretistic cultural environment of Hellenism, mediated this phenomenon. Today the Coptic Orthodox Church of Egypt represents "a return to the apostolic father type leading of the church". Although pharaonic and gnostic influences appear to have contributed to their remarkable eusebeia, the Copts perceive themselves as having abided by the decisions of the first three Church Councils and have respected and upheld the canon.
\end{abstract}

\section{Introduction}

The word Copt originated from the ancient Egyptian word for Memphis, Hah-ka-Ptah - the house or temple of the spirit of Ptah. With the suppression of the prefix and the suffix the stem kaPt or gypt remained, which was then corrupted to the Arabic Qibt (Atiya 1968:16). The Hellenes used Aiguptos for both Egypt and the Nile, and Aiguptoi was used by Origen to distinguish Egyptian Christians from Hellenes (Van der Vliet and Zonhoven 1998:117).

The Copts have a unique identity: inseparable from their pharaonic past, yet intimately associated with the beginning of Christianity. According to early and medieval authors possibly attested by a documentary find in 1958 (Smith 1982:449), Christianity had been brought to Egypt by St. Mark by the beginning of the second half of the first century CE. Today the Coptic Orthodox Church of Egypt constitutes the only living remains of the pharaonic legacy. Von Harnack (1908. II:176-7) recognised "certain cardinal traits of the old national religion" in Egyptian Christianity. From his ideological orientation he perceived this to be the result of a "grafting on to Christianity of the cravings and remnants of the Egyptian religion". However, present-day Copts such as Atiya (1968:20-21) and El Masri Habib (1987. ix) and Jill Kamil (2002. Christianity in the land of the Pharaohs) state the corollary of Von Harnack's observation; they claim that their ancient Egyptian religion "caught a glimpse" of the essential features of Christianity before the birth of Christ.

Modern understanding of hieroglyphic texts and iconography developed less than 200 years ago when Champollion discovered how to decipher hieroglyphs. With the Nag Hammadi discoveries in Egypt in 1946, and the Dead Sea Scrolls in 1947, the greatly increased collection of primary sources from the two centuries before and after the birth of Christ has led to a radical reappraisal of the development of Judaism and Christianity. Atiya (1968:14) claims that many aspects of the general history of Christianity will have to be rewritten in order to incorporate the evidence of the Coptic contribution, which has been 
minimised in the past. In order to see how, and how much, of the pharaonic symbolic system was carried over into Coptic Christianity, it is necessary to examine the mythology of the pharaonic Egyptians and their hieroglyphs.

\section{Ancient Egyptian Cosmology}

Myth functioned as ancient people's tool for ordering their understanding of the world and interpreting cosmological events - what they could not express in abstract terms they expressed by means of their mythic symbols, which were often expressed in ritual. The unique peculiarities of the Egyptian natural environment had a profound effect on their mythology. From the two rhythmic and predictable miracles of the daily rising of the sun and annual rising of the Nile the Egyptians drew their belief that Egypt was the centre of the universe and that renewed life would always be victorious over death. This was the foundational idea of their world-view (Frankfort 1946:44-70).

To the ancient Egyptians all the elements of the universe were of one substance whether physical or spiritual (Frankfort 1946:71), and the name or the idea or a representation is enough to be an effective substitute. Because in their thinking a part can represent the whole, the original could be present in various places. Changes were explained very simply as two different states - a transformation or metamorphosis. The paradox that by manifesting the sacred any object becomes "something else" yet it continues to remain itself for it continues to participate in its surrounding cosmic milieu, is a central concept in Egyptian religion. For them three superhuman principles determined all existence - each is therefore a god in its own right, yet each too is one aspect of a broader, unified conception of deity, which is one: "All the gods are three: Amun, the Sun, and Ptah, without their seconds ... His identity is hidden in Amun, his is the Sun as face, his body is Ptah" (300th Chapter of the Leiden papyrus, quoted by Allen 1980:63).

The new Memphite theology (c. 1250 BCE) made Ptah as supreme creator antecedent to the sun-god Re. Ptah formed a bridge between the intellectual principle of creation and its material realization in the substance of the created world. He was conceived of as the heart (conceptive) and tongue (creative) - the heart releases "everything which is completed" and "it is the tongue which announces what the heart thinks".

\subsection{The King as Divine Ruler}

Chaos was seen to be caused by lack of rule - one of the earliest insignias of Pharaoh was the shepherd's crook - the origin of one of the words meaning "to rule". The good Egyptian ruler was not only the divine warrior king, judge and administrator; he was also the high-priest and herdsman for his people. When the king installed a new vizier into office he cautioned: "Be vigilant concerning (all) that is done in it. Behold, it is the supporting (post) of the entire land ... Authoritative utterance is in thy mouth, perception is in thy heart, and thy tongue is the shrine of justice" (Wilson 1946:99).

The myth of Osiris and Horus legitimises the reigning king and establishes the principle that as Horus, he is both the living "son" and the immediate divine reincarnation of his dead predecessor. Osiris, the father of Horus, represented the life of the deceased pharaoh in the world of the dead. He became the mythical embodiment of the fertile lands of the Nile's eastern delta, which flooded every year and were thus restored to new life. His enemy was Seth, the god of the desert. The transmission of life-force $(\mathrm{Ka})$ from father to son implied the transmission of the father's office to the son and guaranteed the latter's legitimacy (Van Dijk 1992:1705-6). Thus the king was the link between the human and 
divine worlds, but a blood relationship between father and son was not a prequisite. Several sequences of scenes in temples of the New Kingdom (1539-664 BCE) represent an ancient myth in which the sun god Re sires the heir to the throne with an earthly woman of royal descent, thus endowing the progeny with a two-fold legitimacy for kingship - divinity and mortality (Hornung 1983:32).

Isis, whose name may mean "throne" (Griffiths 1980:99) was originally the Egyptian goddess of the royal throne and the mother of Horus. In a fifth Dynasty reproduction of the Opening of the Mouth ritual, whereby the deceased king is granted eternal life, Isis holds a billowing sail in one hand (the hieroglyph for wind or breath of life), and in the other hand the ankh, symbolising eternal life (Witt 1971:39). An early image of Isis represents her as an African woman with black skin and Ethiopian features, seated on a throne with the baby Horus on her lap (Fig. 1 on page 301) and black Madonnas are still to be seen in medieval cathedrals in Europe (Yurco 1996:44). In traditional African cultures, mother and child images embodied the continuity of the life-cycle, and blackness (from the black silt Kemet brought by the Nile) was associated with fertility (Ehrlich 1996:40).

\section{Hellenistic Syncretism of Osiris and Isis, and the Development of the Coptic Language}

The entry of Alexander the Great into Egypt in $332 \mathrm{BCE}$ was the watershed that initiated a thousand years of Graeco-Roman impact on the ancient Egyptian culture. One of Alexander's first actions in Egypt was the establishment of Alexandria on the Mediterranean coast, and Greek became the language of administration. The influx of Greeks brought their art, literature and traditional way of life, and through Ptolemy I's efforts and those of his son, by the second century BCE Alexandria had become a great cosmopolitan centre of learning.

One consequence of Greek rule in Egypt, was syncretism, whereby the Egyptian gods were altered to fit in with Greek concepts. Serapis for instance, was a combination of Osiris and the traditional forms of the cult of the Apis bull (Eddy 1961:271). However, the Memphites did not accept Serapis, and they wanted an Egyptian pharaoh to continue the divine kingship as Horus and Osiris. The Isis cult had begun to spread throughout the Mediterranean world as early as the fourth century BCE, carried by Egyptian sailors. By Ptolemy III's day Isis and Serapis were included, together with deified rulers, in the royal oath. To a large extent, the appeal of Isis was due to the belief that she had power over fate, destiny and fortune (Kakosy 1992:9). The overall appearance and essence of Isis became Greek, even sometimes taking on the features of Aphrodite. The cult of Isis became a universalistic doctrine with a promise of a happy life here below and in the hereafter (Tran Tam Tinh 1982:106,115). In a typical Coptic magical aretology, Isis describes herself as filling a kind of "spiritual black hole". Hellenism had created a void, and anxiety about immortality led to metaphysical questioning. According to Tran Tam Tinh, by their rites, mysteries and by the personal piety of the devotees of Isis, the people of the Mediterranean were made ready for the "quest of the new" (1982:116). Eddy interprets this growing craving for some redemptive religion as a yearning for a Messiah, as a spiritualization of previous historic kingship in Egypt when in the pharaonic period kings were held to be the source of good - of order as opposed to chaos (Eddy 1961:336).

Thus the cultural soil into which Christianity was sown at Alexandria was a seething mix of extremely mobile, searching and diverse ethnic groups. Koine would have conveyed the ideas, concepts and imagery of Hellenism, but subtle counter-influences arose, for 
instance the invention of the Coptic language. During the Ptolemaic era the native Egyptian culture had been maintained by the hereditary priesthood, and the most learned priests had continued to use and elaborate hieroglyphic script. However, germinal efforts were made by the Egyptian priests to devise the Coptic language, by borrowing the letters of the Greek alphabet together with six letters from Demotic script (Lambdin 1983:x) and some Greek words, but expressed the sounds and grammar of the ancient Egyptian language. Thus although the visible, apparently "polytheistic" iconography that was underlying the demotic and hieratic script was eliminated, the rich vocabulary of Coptic still functioned as a vehicle of the intrinsic factor of Egyptian natural environment and metaphor as originally evidenced in their ancient hieroglyphic language.

The half century from 150 to $200 \mathrm{CE}$ was a turning point for Christianity in Alexandria, where an active catechetical school was competing with other philosophical schools, drawing students from all over the Mediterranean. Early Christian teachers well-grounded in Greek philosophy became an integral part of the intellectual world of late antiquity. By the end of the second century CE "Christian Hellenism" had taken root, and Pantaenus and Clement of Alexandria were developing the Coptic language for missionary purposes. The invention of the Coptic language is a prime example of Hellenism as the transformation of the ethnic-national culture of Greece into a new cultural creativeness (Betz 1992:127). Through the invention of Coptic, literacy increased because Coptic was a much easier script than Egyptian. By the third century CE there was a large body of Christian literature available in the Coptic dialects as far south as at Oxyrhynchus. Most of the extant early Christian and gnostic writings are in Sahidic, but today Bohairic Coptic is preserved in some of the church liturgy and scriptural translations.

\section{Orthodoxy and Heresy}

As evidenced by the Nag Hammadi library by the second century there was a distinct Coptic Christianity, both orthodox and heterodox (Danielou 1964:127). Most of the writings are gnostic in character, a few are unquestionably Christian, whilst others are only superficially christianized. Pearson $(1990: 195,209)$ points up the difficulties of extricating the development of Christianity from the web of the important role that Gnosticism played in this process while it too was developing. Chadwick (1991:64) judges from the surviving fragments of The Gospel according to the Egyptians that the character of early Egyptian Christianity appears to have been "none too orthodox", but a papyrus find from Oxyrhynchus of Irenaeus's refutation of Gnosticism dating to the latter half of the second century proves that this was being read in Egypt within a few years of its publication, suggesting that there was interest in Egypt in the maintaining of orthodoxy. Irenaeus includes the church in Egypt among "those that preserve the catholic faith with one heart and one soul" (Haer. 1.10.2, c.180 CE).

There is still no consensus about where and when Gnosticism originated, or what it is (Cook 1998, Coptic lecture notes). It is necessary to distinguish between early possibly preChristian, pre-gnostic elements and the later fully developed system because initially gnostic ideas were applied by New Testament authors. Later there was a polemic against Gnostic authors, and naturally there was an overlap of these two stages. Problems of terminology bedevil this field of historical research, especially because both Christianity and Gnosticism were developing at the same time in a highly syncretistic cultural environment. Pearson (1986:175) comments that the more deeply we go into the questions of orthodoxy and heresy, gnosis and Jewish Christianity, the more things seem to be 
connected. Bauer (1934:59) contested the classical idea of "orthodoxy as a single, pure faith reaching right back to the apostles, with heresy as a corrupt offshoot from the true faith". Several authors have demonstrated that diversity was a characteristic of earliest Christianity (Markus 1980:7).

Williams $(1996: 7,266)$ points out that antiquity quite literally had no single word for the persons whom we today call Gnostics, and suggests that it is time for scholars to develop a new model altogether for the concept of "Gnosticism". However, according to Frend (1984:195-201) Gnosis held a worthy place both in the Jewish and in the earliest Christian scale of values and made a positive contribution to the development of Christianity in that it prepared the way for Christian Platonism because they drew on current philosophy and poetic wisdom, seeking to unite the Christian gospel of redemption with the pagan idea of salvation. Secondly, the Gnostics tried to address the question of how there could be evil in the world, unless the matter from which it was created was irredeemably bad: if God was Goodness, who created evil? If the universe was not governed by Fate (the pagans believed it was), how did one explain calamity, sickness, and sudden death?

\subsection{Clement of Alexandria and the Struggle against Heresy}

The Copts claim Clement of Alexandria (c.150-210CE) as their own Church Father. He worked to reconcile Greek philosophy and logic with ancient Egyptian cosmology and Christianity, believing that Philosophy had been to the Greeks what prophecy was to the Jews - a preparation for Christ, but that the truth of philosophy is mixed with error and must be refined (Malaty 1994:286). Clement's own orthodoxy has sometimes been called into question, largely because of his willingness to see aspects of truth in the most unlikely sources (Pearson 1990:212). In line with the intellectual movement of the day, Clement believed that Christ came to restore true philosophy which had become decayed, and by using quotations, Clement proved that philosophers (Plato) and poets (Homer) had clearly taught the unity, supremacy and goodness of God (Malaty 1994:286).

The following quotation from Clement's writings, which according to Malaty (1994:16) is Alexandrian theology in a nutshell, could be misunderstood to be an indication of a heretical form of Gnosticism, but this is an example of the need to examine exactly what is meant by this particular use of language. "The Word ... became man so that you might learn from Man how man may become god" (Protepticus 1:8:4). According to Enroth (1984:788) one of the components of the occult/mystical world-view and its associated religious expression is the promise of godhood - man as a divine being. Enroth states that all forms of occult philosophy proclaim that the true or "real" self of man is synonymous with God, and that such views are all patterned after the archetypal lie of the serpent in Gen 3:4, "You will be as gods". This confusing perception has been explained by Bishop Paul of the Coptic Orthodox Church as follows: the Copts speak of the "deification of man" in the sense of man allowing God to place himself in us by giving Him the central place in our lives, or "God took our humanity, that man may share His Life." Thus the "Christian gnosis" which Clement promoted was a superior knowledge and a penetration of the Christian mystery. Although he rejected a radical view of Gnosticism Clement viewed the gnostic as a friend of God and the equal of the angels. He saw this gnosis as having come from the apostles and by being transmitted orally, only reached a small number of persons. In Stromata he describes two conversions in Christianity: from paganism to the faith, and from faith to gnosis (Malaty 1994:276). 


\section{The Hellenistic Link between Pharaonic Culture and Coptic Christianity, and the Presaging of Christianity in Pharaonic Religion}

Hornung (1983:125) suggests that the key to understanding the monotheistic/polytheistic puzzle of Egyptian religion is that we are facing a different logic - "eine mehrwertige Logik". Brandon $(1975: 172)$ makes a plea for more research on the evidence of early Christianity in the iconography of the time. For the ancient Egyptians the world in its entirety is also the image ( $t j t)$ of the primordial source from which it was produced. This concept was a means of capturing reality through symbols - in effect, all creation is a hieroglyphic text of the creator's original concept, but symbols may exhibit different meanings in different contexts. According to Grabar (1968:xlvi) almost everything in the first Christian images was dictated by the pagan models they followed, and it was because of this that the new, Christian images were understandable to their contemporaries, for instance one of the earliest known representations of Christ, is as the Good shepherd - a direct association with the very ancient Egyptian concept of their divine pharaoh. The following aspects of Egyptian iconography and literature may also have contributed to the "processing" and "mediating" of the cosmology of the pharaonic past to the Coptic Christians.

In Egyptian religion the names of gods became the building-blocks for expanded definitions of divinity (Kemp 1989:29). For instance in one version of the Book of the Dead, Osiris is defined with the names of five gods to enrich the imagery by which he is to be understood Another example is the sun-god who says "I am Khephri in the morning, Ra at midday, Atum in the evening", and "'Hidden' is his name as Amon, he is Re in face, and his body is Ptah" (Leyden hymns to Amon). Practically every town in ancient Egypt possessed some kind of a triad of gods. This led to the concept of unity in plurality by making three stand for plurality: "All gods are three: Amon, Re and Ptah, and there is no second to them.

Triadic ontological structures are characteristic of Neoplatonism. Pearson (1990:66) notes that the Greek term used to indicate that God is triple powerful, may have had a Gnostic origin, and this concept is expressed in Coptic as meaning that God has three powers: Existence, Life and Intelligence, or, "He is Life, Intelligence and That Which is". The hellenistic expression "God is one" used by the earliest Christian communities is derived from the service of Sarapis ("One is Zeus-Serapius") which originated from the pharaonic form "one is Amon". An amulet in the British Museum (Mickel, S 2001. "Die Magishen Gemmen im Brittishen Museum"), dating from c.100 CE bears a text which reads "One is Bait, one is Hathor, one is Akori - to these belongs one power. Be greeted, father of the world, be greeted, God in three forms". "This could imply that "God is one", which the Coptic Christians to this day repeat during prayer, just prior to saying amen.

The earliest Coptic baptismal symbol (Arnold 1970 repr.71) has a nine-fold structure which strikes a chord with the original pharaonic conception of the creator of the Ennead, in that the Nine forms a unified yet separate totality concerning the Creator, and also echoes the ancient Egyptian concept of a triad of gods which expressed their concept of unity in plurality.

"I believe

$\begin{array}{lll}\text { in God } & \text { the Father } & \text { the All-powerful } \\ \text { in Jesus Christ } & \text { the Son } & \text { our Lord } \\ \text { in the Holy Spirit } & \text { the Church } & \text { the Resurrection of the Flesh." }\end{array}$

The perception that as a mother holding the child Horus on her lap or to her breast, Isis "with her long, rippling hair and lunar aureole supplied the essential iconography, and perhaps also some of the early liturgical material, for the subsequent cult of the Blessed Virgin" (Green 1990:412), is generally recognised amongst scholars of Coptic history. Minute details became highly significant in terms of the specific Christian content, for 
example a Coptic icon of the Madonna and Jesus always has the baby Jesus held by Mary in such a way that she is at his right hand because that conveys scriptural significance (Fig. 2 on page 301), yet she is usually seated on a throne just as Isis would have to be. Atiya (1968:20) states that the story of the Annunciation, the Holy Ghost and the miraculous virgin birth of Jesus were not new to the Egyptian mind. Features of Isis also appear in the birth story of the Messiah in Rev. 12, where the mother is described as having the zodiac on her head and clothed with the rays of the sun.

According to Atiya (1968:20) the divinity and humanity of Jesus was expressed in Osiris, who was perceived to be both god and man. In addition to belief in the existence after death of the king because he was divine, by the Middle Kingdom, judgement after death for ordinary mortals was also clearly stated, with the possibility of non-existence if the heart fails the weighing test. Surviving letters from Egypt addressed to the dead also attest to a belief in the continuity between life and the afterlife, and the expectation of reunification with deceased family members (Van te Velde 1992:1745).

Groves records an example from Antinoe where a supposed Christian priest is depicted on the outer wrapping of a coffin holding a cup in one hand and corn-ears in the other, with a cross on his shoulder and the boat of Isis below. The placing of the Eucharistic elements with the dead witnesses to a belief in sacramental efficacy before that doctrine was developed by the Church (Groves 1948:41). This may have been mediated by the assimilation of Isis to Demeter, as is evidenced in a statue of Isis as Demeter holding corn ears instead of the pharaonic sistrum (Witt 1971:261).

The crux ansata a Christian adaptation of the ankh, was used in both Christian and pagan contexts, sometimes in combination with the Latin cross (Fig 3 on page 301), which presumably was used by Christians from at least the time of Clement of Alexandria, because he refers to it as the sign par excellence of the Lord (Stromateis 6, 190-215 CE). The crux ansata was used beyond the 5th century CE, and has also been found in combination with a winged sun-disk (Bowen 2000:1,11,12). Irenaeus says that the cross as a plough "hoed the uncultivated land". Justin compares it to a wheel which "mows, cuts, uproots" (Danielou 1973:275). A Coptic icon screen at the Monastery of Anba St Bishoi has a very intricate design which they call the moving cross because it is made up in the form of a wheel, to symbolise the spread of the gospel over the whole world.

Finally the frequently used Coptic iconographical theme of St. George and the Dragon is identifiable with the apocalyptic "Combat Myth" (Clifford 1999:4) as represented by Horus and his struggle against the god of evil, Seth, and is also reflected in the book of Revelation.

\section{Conclusion}

"Ever since the creation of the world his invisible nature, namely, his eternal power and deity, has been clearly perceived in the things that have been made" (Romans 1:20).

The answer to the question of what enabled the pharaonic Egyptians to "glimpse the Light of Christianity beforehand" may be found in the Egyptian genius for close observation of the minusculae of nature as clearly demonstrated in their artwork and hieroglyphs. The gift of observation of fine detail in the natural environment must at least in part, be the result of living very close to a unique and remarkable natural environment. Assman (1997:114) recognises the hieroglyphic representation of things as signs which formed a virtually complete inventory of ecological aspects of the created world as a kind of Platonism. Plato interprets the visible world as the infinite material reproduction of a finite set of immaterial ideas of "absolute truth - Level I", and this same set is represented by the hieroglyphic system, which reproduces the world of things as signs. Swedenborg (1916:19) expressed 
this principle as follows: "Each and all things that exist in the natural world, even to the smallest single thing, correspond to spiritual things, and thence signify them".

Luckert (1991:180) goes so far as to state that Christianity represents a return to Egypt by way of mythology, theology and ritual, and that ancient Egyptian theology made it possible for educated hellenistic Christians to believe in an only-begotten Son who came into the world in the form of the logos, as the divine creative command, or the Word made visible: "In all the religious literature from the so-called hellenistic period, there is no better summary of ancient orthodox Egyptian theology than the prologue to the gospel of John". The evidence presented here suggests that the Egyptian Christians, through all the syncretistic pressures of hellenism, remained faithful to the wisdom of their pharaonic ancestors. Even though pharaonic and gnostic influences appear to have contributed to their remarkable eusebeia, the Copts claim that they have abided by the decisions of the first three Church Councils and as having respected and upheld the canon. Today the Coptic Orthodox Church of Egypt represents, in the words of the current Coptic Patriarch, "a return to the apostolic father type of leading of the church". He stresses that they aim at renewal by expressing ancient doctrine, theology and traditions in a contemporary form that is understandable by their youth.

Shoucri (2001:140) suggests that "the time has probably come for a ... reconciliation between the ancient Egyptian philosophy and the monotheistic religions that followed it" and quotes Albert Schweitzer's epilogue to his book My Life and Thought: "Christianity has need of thought that it may come to the consciousness of its real self".

\section{BIBLIOGRAPHY}

Allen, JP 1980. Genesis in Egypt. Yale: New Haven.

Arnold, E 1970. The Early Christians. Baker Book House:Grand Rapids.

Assman, J 1997. Moses the Egyptian. The Memory of Egypt in Western Monotheism. Harvard University Press: Manchester.

Atiya, AS 1968. A History of Eastern Christianity. SCM Press Ltd: London.

Bauer, W 1934 (repr. 1971). Orthodoxy \& Heresy in Earliest Christianity. Philadelphia: Fortress Press.

Betz, HD 1992. Hellenism, in: Freedman, DN (ed.), 127-135.

Bowen, GE 2000. The ankh in early Christian iconography: Some reflections in light of recent discoveries at Kellis. Monash University: Victoria, Australia.

Bowman, AC 1986. Egypt after the Pharaohs. British Museum Publications: London.

Brandon, SFG 1975. Christ in Verbal and Depicted Imagery: A Problem of Early Christian Iconography, in Neusner, J (ed.),165-172.

Celenko, T (ed.) 1996. Egypt in Africa. Indiana University Press: Indianapolis.

Chadwick, H 1991. Heresy and Orthodoxy in the Early Church. Galliard: Norfolk.

Clifford, RJ 1999. The Roots of Apocalypticism in Near Eastern Myth, in Collins (ed.), pp. 3-38.

Collins JJ (ed.) 1999. The Encyclopaedia of Apocalypticism Vol I. NY: Continuum.

Cook, J 1998. Unpublished Coptic lecture notes, Dept. Ancient Studies, University of Stellenbosch.

Danielou, Jean and Marrou, H 1964. The Christian Centuries Vol I. Longman and Todd: London.

Danielou, Jean 1973. A History of Early Christian Doctrine Vol 2. Longman and Todd: London.

Eddy, SK 1961. The King is Dead, Studies in Near Eastern Resistance to Hellenism 334-31BC. University of Nebraska Press: Lincoln.

Ehrlich, J 1996. Mother and Child figures in Africa, in Celenko, T (ed.), 40-42. 
Ellwell, WA (ed.) 1984. Evangelical Dictionary of Theology. Baker House: Michigan.

El Masri Habib, I 1987. The Story of the Copts - The true story of Christianity in Egypt. Coptic Bishopric for African Affairs: California.

Enroth, RM 1984. The Occult, in: Elwell, WA (ed.), 787-788.

Frankfort, H 1946. Before Philosophy. University of Chicago Press: Chicago.

Freedman, DN 1992. Anchor Bible Dictionary. Doubleday: NY

Frend, WHC 1984. The Rise of Christianity. London:Longmann and Todd.

Grabar, A 1968. Christian Iconography: A study of its Origins. Princeton: Princeton University Press.

Green, P 1990. Alexander to Actium. LA: Univeristy of California Press.

Griffiths, JG 1980. The Origin of Osiris and his Cult. Leiden: EJ Brill.

Groves, CP 1948. The Planting of Christianity in Africa Vol. I. London: Lutterworth Press.

Hornung, E 1983. Conceptions of God in Egypt. The One and the Many. (tr. J Baines) Manchester: Manchester University Press.

Kakosy, L 1992. Egypt in ancient Greek and Roman Thought, in Sasson, JM (ed.), 3-13.

Kemp, BJ 1989. Ancient Egypt. London: Routledge.

Lambdin, TO 1983. Introduction to Sahidic Coptic. Macon, GA: Mercer University Press.

Luckert, KW 1991. Egyptian Light and Hebrew Fire. NY: State University of New York Press.

Malaty TY 1994. The School of Alexandria. Book One before Origen. Jersey City: St. Marks Coptic Orthodox Church.

Markus, RA 1980. The Problem of Self-Definition: From Sect to Church, in: Sanders, EP, 1-15.

Neusner, J (ed.) 1975. Christianity, Judaism and other Graeco-Roman Cults. Brill: Leiden.

Pearson, BA 1986. Christians and Jews in First-Century Alexandria. HTR 79:1-3. pp. 206-16.

Pearson, BA 1990. Gnosticism, Judaism, and Egyptian Christianity. Minneapolis: Fortress Press.

Sanders, EP 1980. Jewish and Christian Self-definition. Vol. I The Shaping of Christianity in the Second and third Centuries. London, SCM.

Sanders, EP and Meyer, B F (eds.) 1982. Jewish and Christian Self-definition Vol II. Self definition in the Graeco-Roman World. London: SCM Press.

Sasson, JM (ed.) 1992. Civilizations of the Ancient Near East. NY: Scribners.

Shoucri, RM 2001. Ancient Egyptian Philosophy and Hermetic Tradition. Coptologia, Vol XVII, pp. $117-142$

Smith, M 1982. Clement of Alexandria and Secret Mark: The score at the end of the first decade. HTR 75:4 (449-61).

Swedenborg, E 1916. Arcana Coelestia Vol III. London: The Swedenborg Society.

Tran Tam Tinh 1982. Serapis and Isis, in: Sanders, EP and Meyer, BF (eds.), 101-117.

Van der Vliet, J and Zonhoven, L 1998. Het Koptisch. Phoenix 44, 2/3.

Van Dijk, J 1992. Myth and Mythmaking in Ancient Egypt, in: Sasson, 1697-1709.

Van te Velde, H 1992. Theology, Priests and Worship in ancient Egypt, in: Sasson, 1731-1749.

Von Harnack, A 1908. Mission and expansion of Christianity in the First Three Centuries Vol II.

Wenig, S 1969. The Woman in Egyptian Art (tr. B Fischer) Erfurt: Drukkerei Forthirtt.

Williams, M A 1996. Rethinking 'Gnosticism'. An argument for dismantling a dubious category. Princeton: Princeton University Press.

Wilson, JA 1946. The Function of the State, in: Frankfort, 71-102.

Witt, RE 1971. Isis in the Graeco-roman World. London: Thames and Hudson.

Yurco, FJ 1996. Mother and Child Imagery in Egypt and its Influence on Christianity, in: Celenko, 43-45. 


\section{FIGURES}

Figure: 1



Figure: 3



Figure: 2



Fig. 1.

Isis's early image with baby Horus on her lap (Clenko 1996).

\section{Fig. 2.}

Tomb stelae from Medinet el Faiyum (Wenig 1969).

Fig. 3.

Stela from Byzantine period juxtaposing the Coptic cross and the traditional Egyptian ankh (symbol of life) (Bowman 1986). 